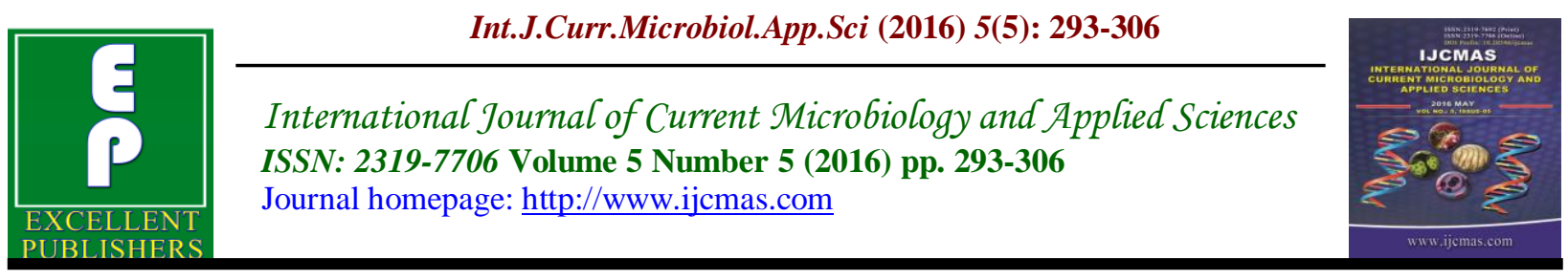

Original Research Article

http://dx.doi.org/10.20546/ijcmas.2016.505.032

\title{
Utilization of Microwave Treatments for Germination and $\alpha$-amylase Characteristics in Some Cereals
}

\author{
Firdaws A. Al Mashhdani* and Shno Salam Muhammed \\ Food Technology-Agriculture College-Salahaddin University, Iraq \\ *Corresponding author
}

\begin{tabular}{ll}
\hline & A B S T R A C T \\
& $\begin{array}{l}\text { In the present study, the effect of the biophysical microwave irradiation with } \\
\text { different exposure times, on the development and germination of Wheat (Triticum } \\
\text { spp), Barley (Hordeum vulgare L.) and Oat (Avena sativa L) after steeping, seeds }\end{array}$ \\
in Arbil city was evaluated, the study also include comparison of $\alpha$-amylase yield \\
produced by the treated and untreated cereals, partial purification and \\
characterization of the enzyme from the best source of enzyme treated malted oat.
\end{tabular}

\section{Introduction}

$\alpha$-Amylases (EC 3.2.1.1) are endoenzymes that catalyze the cleavage of $\alpha-1,4-$ glycosidic bonds in the inner part of the amylose or amylopectin chain and related polysaccharide. The end products of $\alpha$ amylase action are oligosaccharides, with an $\alpha$-configuration and varying lengths, and $\alpha$ limit dextrins, which are branched oligosaccharides (Van der Maarel et al., 2002). These enzymes can be obtained from cereal, fungal, bacterial and biotechnologically altered bacterial sources. (Synowiecki et al., 2007). 
$\alpha$-Amylases, are among the most valuable enzymes, starch depolymerization which is basis for several industrial processes, which generally require $\alpha$-Amylases with high activity profile. Thus much research effort to increase the $\alpha$-Amylases in germination processes of cereal were performed.

The use of physical methods for plant growth stimulation attracts more and more the attention of agricultural producers as an alternative of chemical amelioration, which offers ways to improve food quality without impairing its safety (Aladjadjiyan, 2011). Most perspective factors are the treatment with ultrasound and microwave. The interest in the use of physical methods of plant growing stimulation has increased (Carbonell et al., 2005 and Soltani et al., 2006). All living processes are highly dependent on energy exchange between the cell and the environment In the case of physical treatment the energy introduced in the cell creates conditions for molecular transformations and as a result, the necessary substances are provided for the cell. This is the core concept in "quantum agriculture" that has been intensively discussed in the last years (Aladjadjiyan, 2007).

The treatment with microwave radiation can cause transitions of electrons between rotation sublevels. Transitions between vibration levels of organic molecules are in near Infrared (IR) regions, and those between rotation levels are in far IR regions and near microwave regions of the electromagnetic spectrum (Mullin, 1995).

The usage of these methods in the agriculture production will enable intense and more quantitative production of enzymes, protein....etc as well as the protection of the environment, but seeds exposed to high level of radiation will not germinated. Seed exposed to intermediated level of radiation may actually exhibit higher growth rates and yield of enzymes. Rajagopal (2009) was reported that exposure to $650 \mathrm{~W}, 2.45 \mathrm{GHz}$ microwaves for about $30 \mathrm{~s}$ is sufficient to ensure a high rate of germination by some mechanism that is not as yet fully understood.

Aladjadjiyan (2010) has stated that the magnetic field intensity and seeds temperature increased progressively with microwave pretreatments of $5,10,15,20$ and $25 \mathrm{sec}$ compared with controls and an increase in $\alpha$-amylase activity. Studies on the effect of electromagnetic microwave irradiation of $(2.45 \mathrm{GHz})$ on wheat were conducted by (Bhaskara et al., 1995 and Khalafallah et al., 2009) who also detected increased germination.

Literature in this field of study indicated that microwave radiation had a positive effect on some plants and had an adverse effect on others; which suggested that microwave radiation effects may depend on: radiation frequency, exposure period and the environmental conditions (Khalafalah et al., 2009 and Aladjadjian, 2012).

A process for the isolation of amylase rich fraction from malted cereals was developed (Nirmala and Muralikrishna, 2002). $\alpha$ amylase has been purified and characterized from different sources and different cereals using conventional as well as classical method., These methods include dialysis, ion exchange, affinity chromatography, sephacryl-S-200 gel filtration, glycogenSepharose and chromatofocusing can be used to purify enzymes. (Muralikrishna and Nirmala, 2005).

The present study aimed to:-

Investigate the effect of microwave 
irradiation treatments on the germination of some different cereals (Wheat, Barley and Oat).

Figure out the best source of treated cereals to produced $\alpha$-amylase with the highest specific activity to be used further throughout the study.

Partial purification of $\alpha$-amylase produced from the richest source, and to study its properties and its kinetic parameters.

\section{Materials and Methods}

\section{Raw Materials}

\section{Type of Grains}

Barley (Hordeum vulgare L.), Wheat (Triticum spp) and Oat (Avena sativa L) grain sample with moisture content of (11.8, 11.7 and $10 \%$ ( for barely, wheat, and oat respectively were taken from Research centre in Erbil, it was pre stored in dry place at $20^{\circ} \mathrm{C}$.

\section{Microwave Treatment}

The influences of microwave irradiation with wavelength $12 \mathrm{~cm}$ on seeds have been investigated. A magnetron 1042GL with frequency of radiation $2.45 \mathrm{GHz}$ and maximum output power $900 \mathrm{~W}$ according to supplier's data has been used as microwave source. Maximum density of irradiation has been estimated at $45 \mathrm{~kW} / \mathrm{m} 3$. The estimation has been obtained by dividing the output power of the device $(900 \mathrm{~W})$ to the working volume having dimensions $510 \mathrm{~mm}$ (W) $\times 310 \mathrm{~mm}(\mathrm{H}) \times 404 \mathrm{~mm}(\mathrm{D})$.Seeds have been soaked in distilled water, presuming that the imbibed water plays an important role in the absorption of the energy of microwave radiation. Seeds for the experiment have been distributed in 5 replicates each containing 20 seeds. The variants differ by the time of exposure to the microwave radiation. Seeds have been exposed to the microwave radiation for $0 \mathrm{~s}$ (control), 10s, 20s, 30 s, 40s, 50s, 60 s, 90 s. a modifications of output powers of magnetron as $450 \mathrm{~W}$, corresponding to intensities of $22.5 \mathrm{~kW} / \mathrm{m} 3$, have been applied.

\section{Extraction of Enzymes from Malt}

In this research commonly $50 \mathrm{mM}$ potassium-phosphate buffer with $\mathrm{pH}=7$ was used as the best extraction solution (Osman, 2002). Approximately, $0.75 \mathrm{~g}$ malt flour was weighed into centrifuge tubes and $4 \mathrm{ml}$ extraction solution was added with mixing. Extraction was performed for 30 min at $30{ }^{\circ} \mathrm{C}$ with regular vortexing for $5 \mathrm{~s}$ at 5 min intervals and was terminated by centrifugation for $10 \mathrm{~min}$ at $3000 \mathrm{~g}$. This experiment was carried in duplicate.

\section{Enzyme Activity Assay}

$\alpha$-amylase was assayed by measurement of maltose related as a result of $\alpha$-amylase action on starch according to the procedure of (Bernfeld, 1955). This method measured the activity of $\alpha$-amylase by performing reaction using 3, 5-dinitrosalicylic acid (DNSA).

\section{Protein Determination}

The method of Lowery et al (1951) was used for the estimation of protein concentration. Bovine Serum Albumin (BSA) was used as standard

\section{Partial Purification of $\alpha$-amylase:}

\section{Ammonium Sulphate Precipitation:}

The enzyme was precipitated with ammonium sulphate at its 30, 40, 50, 60, 70 and $80 \%$ of saturation (w/v) and centrifuged 
at $10000 \mathrm{rpm}$ at $4{ }^{\circ} \mathrm{C}$ for $15 \mathrm{~min}$. Then the pellets were dissolved in $10 \mathrm{ml}$ of potassium phosphate buffer $0.05 \mathrm{M}$ with $\mathrm{pH} 7$ and stirred at 500rpm. The $\alpha$-amylase activity and protein concentration was determined.

\section{Dialysis}

Active fraction of enzyme from precipitation step with $50 \%$ saturation was dialyzed against $(0.01 \mathrm{M}$, Potassium phosphate $\mathrm{pH} 7.0$ buffer) for $24 \mathrm{hr}$ at $5{ }^{\circ} \mathrm{C}$ and the enzyme activity and protein content was determined.

\section{Gel-filtration Chromatography}

Preparation of the gel column and the fractionation procedures was determined as previously mentioned by Ammar (1975). For this purpose, column $(1.6 \times 65 \mathrm{~cm})$ and Sephadex G- 75 (Pharmacia fine chemicals) "practical size $200 \mu$ " had been used, flow rate of $(18 \mathrm{ml} / \mathrm{hr})$. Fraction of $2 \mathrm{ml}$ was collected by fraction collector at $5{ }^{\circ} \mathrm{C}$. The protein content in all fractions were monitored spectrophotometrically at $280 \mathrm{~nm}$. Active fraction were pooled, assayed for total enzyme activity and protein.

\section{Characterization of $\alpha$-amylase}

\section{Effect of Temperature on $\alpha$-Amylase}

$\alpha$-Amylase activities were determined at a temperature range of $20-70^{\circ} \mathrm{C}$ (with an interval of $5^{\circ} \mathrm{C}$ ) with $1 \%$ soluble starch as substrate. The relative activity at different a temperature was calculated, taking the maximum activity obtained as $100 \%$.

\section{Effect of pH on $\alpha$-amylase activity}

$\alpha$-Amylase activities were determined at various $\mathrm{pH}$ values using different buffers ranged from 3.0 to 10.0 with the same ionic strength of $0.2 \mathrm{M}$

\section{Determination of Kinetic Constants}

The activity of the enzyme was assayed in $0.05 \mathrm{M}$ sodium acetate buffer $(\mathrm{pH} 5.0)$ with varying substrate concentrations ranging from 0.2 to $2.0 \mathrm{mg} / \mathrm{ml}$. $\mathrm{Km}$ and $V \max$ were calculated from Linerweaver and Burk plot (Lineweaver and Burk, 1934).

Determination of Molecular Weight AAmylase by Sodium Dodecyl SulfatePolyacrylamide Gel Electrophoresis (SdsPage)

Uniformity and molecular weight of purified $\alpha$-amylase were detected by denaturing SDS-PAGE method according to Laemmli method (1970) with little modification.

\section{Statistical Analysis}

The data were analyzed using statistical program (SAS 2002, 2003) analysis system depending on (general liner mode.).

\section{Results and Discussion}

The Effect of Microwave Treatment with different Exposure Time on malted

\section{Wheat, Barley and Oat $\alpha$-amylases Activities}

Table (2) showed that microwave treatment at $10 \mathrm{sec}$ for wheat and $30 \mathrm{sec}$ for barely and oat $(1699.90,2913.15)$

The best specific activity was with oat seeds were irradiated by microwave irradiated at $30 \mathrm{sec}$ from the time of exposure and $450 \mathrm{~W}$ energy.

\section{Precipitation of the Enzyme}

Precipitation of $\alpha$-amylase from untreated oat seeds and microwave treated oat seeds 
by ammonium sulfate at different saturation, the best concentration for ammonium sulfate saturation was $50 \%$ for control and microwave treatment which gave a high specific activity of 5538.37 and $7123.78 \mathrm{U} / \mathrm{mg}$ respectively increase 2.54 and 1.84 in purification fold respectively and yield 30.78 and 32.90 respectively.

\section{Purification of $\alpha$-amylase}

The active portion the precipitate of 50\% enzyme was dissolved in $8 \mathrm{ml}$ potassium phosphate buffer and dialyzed against (0.01M, PH 7.0 potassium phosphate buffers for $24 \mathrm{~h}$ at $4^{\circ} \mathrm{C}$ ) as showed in table 18 and 19 , this process gave specific activity of 6697.92 and $12592.47 \mathrm{U} / \mathrm{mg}$ protein 3.07 and 3.26 in purification fold and yield 15.54 and 19.69 for control and MW treatment respectively.

Kumar et al., (2005) succeeded in purification of $\alpha$-amylase from malted sorghum using two steps include ion exchange chromatography on DEAE cellulose then gel filtration on sephadex G75 with 24.7 fold $f$ purification and about $17.1 \%$ yield. Purification method used by Machaiah and Vakil, (1981) for $\alpha$-amylase from gamma irradiation wheat was performed by precipitation of enzyme from the crude extract and isolated as enzymeglycogen complex. several researchers also used sephadex G-75 for purification $\alpha$ amylase from microorganisms and the results were similar in salting out and chromatography procedures, for Rhizupas microspores Vijayaraghavan et al., (2011)

This can be explained by the fact the activity of an enzymatic reaction depended on the temperature, with increasing temperature the kinetic energy for each of the enzyme and substrate which leads to increase the possibility of collisions between their molecules up to the optimum temperature which promote potential binding between them (Segel, 1976), the enzyme activity decrease by increasing temperature above the optimal temperature due to denaturation process of the protein part of the enzyme and the loss of its natural properties(Maciunska and Synowiecki, 1998 and Zhou and Chen, 2001).

\section{$\alpha$-amylase properties}

\section{Effect of Temperature on Activity}

The effects of temperature on $\alpha$-amylase activity of oat (treated and untreated) seeds was studied by determining the activity between $20-70^{\circ} \mathrm{C}$, as exposed in figure 12 and 13 the enzyme activity increase gradually with temperature rising up to $35^{\circ} \mathrm{C}$, at $50^{\circ} \mathrm{C}$ the enzyme showed maximum activity, above $50^{\circ} \mathrm{C}$ decreasing in enzyme activity was observed, and the activity was dropped to less than $37 \%$ and $35 \%$ at $70^{\circ} \mathrm{C}$ for control and microwave irradiation respectively.

Machaiah and Vakil, 1981 reported that the low dose of irradiation had no appreciable effect on physiochemical properties of $\alpha$ amylase. They found no significant difference between treated wheat seeds and untreated seeds.

The enzyme activity was optimal at $50^{\circ} \mathrm{C}$. This value is similar to the one reported for ragi $\alpha-2$ amylase (Nirmala and Muralikrishna, 2003b) and in local malted barley by ( Majeed et al., 2011) in wheat (Triticum Aestivum) by (Mohamed et al., 2009). However, slightly higher temperature optima $55^{\circ} \mathrm{C}$ was reported for amylases from pearl millet (Adelaide and Varriano, 1981), malted barley, malted sorghum ((MacGregor, 1978 and Kumar et al., 2005). 


\section{Effect of PH on $\alpha$-amylase Activity}

The effect of PH on oat seed purified $\alpha$ amylase activity for control and $30 \mathrm{sec}$ irradiated sample, using the different $\mathrm{PH}$ ranged from 3 to 9 at $40^{\circ} \mathrm{C}$ for $10 \mathrm{~min}$. From fig (16) and fig (17), the optimum $\mathrm{PH}$ was found to be 5 for $\alpha$-amylase of untreated and treated seeds. Also aboard PH for enzyme activity was noticed which ranged from 4 to 7.
The results of the present study were agree with many researchers (Tkachuk and Kruger, 1974; Beers and Duke, 1990 and Nirmala and Muralikrishna, 2003b) reported a similar acidic $\mathrm{pH}$ range 4.5 to 6.5 for activity of $\alpha$-amylase from wheat, shoots and cotyledons of pea (Pisum sativum L.) seedlings and finger millet respectively. Also Majeed et al., (2011) observed that the enzyme purified from malted barley exhibited optimum activity at PH 5.

Table.1 The Effect of Microwave Treatments on A-Amylase Activity with different Exposure Time in Malted Wheat, Barley and Oat Seeds

\begin{tabular}{|c|c|c|c|c|c|}
\hline Type & Tool & Time & $\begin{array}{c}\text { Enzyme activity } \\
\mathrm{IU} / \mathrm{ml}\end{array}$ & $\begin{array}{c}\text { Protein } \\
\text { concentrate } \\
\mathrm{mg} / \mathrm{ml}\end{array}$ & $\begin{array}{l}\text { Specific activity } \\
\text { IU/mg }\end{array}$ \\
\hline \multirow[t]{7}{*}{ Wheat } & \multirow[t]{7}{*}{ Microwave } & Control & $1168.6^{\mathrm{r}, \mathrm{s}}$ & $1.11^{\mathrm{r}}$ & $1052.79^{\mathrm{u}}$ \\
\hline & & $10 \mathrm{sec}$ & $1835.9^{\mathrm{q}}$ & $1.08^{r}$ & $1699.90^{p}$ \\
\hline & & $20 \mathrm{sec}$ & $1730.3^{q}$ & $1.11^{r}$ & $1558.82^{q}$ \\
\hline & & $30 \mathrm{sec}$ & $1659.4^{\mathrm{q}}$ & $1.13^{r}$ & $1468.99^{\mathrm{q}, \mathrm{r}}$ \\
\hline & & $40 \mathrm{sec}$ & $1356.4^{\mathrm{r}}$ & $1.10^{r}$ & $1233.09^{\mathrm{S}}$ \\
\hline & & $50 \mathrm{sec}$ & $1185.0^{\mathrm{r}, \mathrm{s}}$ & $1.00^{\mathrm{s}}$ & $1185.01^{\mathrm{t}}$ \\
\hline & & $60 \mathrm{sec}$ & $890.7^{t}$ & $0.98^{\mathrm{s}}$ & $908.87^{v}$ \\
\hline \multirow[t]{6}{*}{ Barley } & \multirow[t]{6}{*}{ Microwave } & Control & $3332.5^{\mathrm{m}}$ & $1.65^{\mathrm{m}, \mathrm{n}}$ & $2019.69^{n}$ \\
\hline & & $10 \mathrm{sec}$ & $4141.9^{\mathrm{K}}$ & $1.68^{1, \mathrm{~m}}$ & $2465.41^{i}$ \\
\hline & & $20 \mathrm{sec}$ & $4380.0^{j}$ & $1.81^{\mathrm{k}}$ & $2419.13^{i}$ \\
\hline & & $30 \mathrm{sec}$ & $5360.2^{\mathrm{h}}$ & $1.84^{\mathrm{j}, \mathrm{k}}$ & $2913.15^{f}$ \\
\hline & & $40 \mathrm{sec}$ & $3577.1^{1}$ & $1.93^{\mathrm{i}}$ & $1853.55^{\circ}$ \\
\hline & & $50 \mathrm{sec}$ & $3049.1^{\mathrm{n}}$ & $1.98^{\mathrm{h}}$ & $1539.94^{\mathrm{q}}$ \\
\hline \multirow[t]{7}{*}{ Oat } & \multirow[t]{7}{*}{ Microwave } & Control & $4605.0^{i}$ & $2.09^{f}$ & $2203.34^{1, \mathrm{~m}}$ \\
\hline & & $10 \mathrm{sec}$ & $6007.3^{f, g}$ & $2.03 \mathrm{~g}$ & $2949.26^{\mathrm{f}}$ \\
\hline & & $20 \mathrm{sec}$ & $6236.7^{\mathrm{e}}$ & $2.08^{f, g}$ & $2998.41^{\mathrm{d}, \mathrm{e}, \mathrm{f}}$ \\
\hline & & $30 \mathrm{sec}$ & $8054.3^{\mathrm{a}}$ & $2.11^{\mathrm{e}, \mathrm{f}}$ & $3817.20^{\mathrm{a}}$ \\
\hline & & $40 \mathrm{sec}$ & $6929.2^{c}$ & $2.32^{\mathrm{a}}$ & $2986.72^{\mathrm{e}, \mathrm{f}}$ \\
\hline & & $50 \mathrm{sec}$ & $5^{284 . P 5^{h}}$ & $2.17^{\mathrm{c}, \mathrm{d}}$ & $2435.06^{i}$ \\
\hline & & $60 \mathrm{sec}$ & $4375.6^{j}$ & $2.04^{\mathrm{g}}$ & $2144.90^{\mathrm{m}}$ \\
\hline
\end{tabular}


Table.2 Purification of Untreated Oat Seeds $\alpha$-amylase

\begin{tabular}{|l|c|c|c|c|c|c|c|}
\hline $\begin{array}{c}\text { Purification } \\
\text { Steps }\end{array}$ & $\begin{array}{c}\text { Volume } \\
\text { Ml }\end{array}$ & $\begin{array}{c}\text { Enzyme } \\
\text { activity } \\
\text { IU/ml }\end{array}$ & $\begin{array}{c}\text { Protein } \\
\text { concentrat } \\
\text { e mg/ml }\end{array}$ & $\begin{array}{c}\text { Total } \\
\text { activity } \\
\text { IU }\end{array}$ & $\begin{array}{c}\text { Specific } \\
\text { activity } \\
\text { IU/mg }\end{array}$ & $\begin{array}{c}\text { Purification } \\
\text { fold }\end{array}$ & $\begin{array}{c}\text { Yield } \\
\%\end{array}$ \\
\hline Crud enzyme & 50 & 4605.1 & 2.13 & 230255 & 2162.01 & 1 & 100 \\
\hline $\begin{array}{l}\text { Ammonium } \\
\text { sulfate 50\% }\end{array}$ & 8 & 7089.29 & 1.28 & 56714.32 & 5538.5 & 2.56 & 24.63 \\
\hline Gel filtration & 22 & 1415.26 & 0.042 & 31153.72 & 33696.66 & 15.58 & 13.52 \\
\hline
\end{tabular}

Table.3 $\alpha$-amylase in Oat Seeds Purification Table (microwave treatment)

\begin{tabular}{|l|c|c|c|c|c|c|c|}
\hline $\begin{array}{c}\text { Purification } \\
\text { Steps }\end{array}$ & $\begin{array}{c}\text { Volume } \\
\text { Ml }\end{array}$ & $\begin{array}{c}\text { Enzyme } \\
\text { activity } \\
\text { IU/ml }\end{array}$ & $\begin{array}{c}\text { Protein } \\
\text { concentrate } \\
\mathrm{mg} / \mathrm{ml}\end{array}$ & $\begin{array}{c}\text { Total } \\
\text { activity } \\
\text { IU }\end{array}$ & $\begin{array}{c}\text { Specific } \\
\text { activity } \\
\text { IU/mg }\end{array}$ & $\begin{array}{c}\text { Purificati } \\
\text { on fold }\end{array}$ & $\begin{array}{c}\text { Yield } \\
\%\end{array}$ \\
\hline $\begin{array}{l}\text { Crud } \\
\text { enzyme }\end{array}$ & 50 & 8054.44 & 2.03 & 402722 & 3853.79 & 1 & 100 \\
\hline $\begin{array}{c}\text { Ammonium } \\
\text { sulfate 50\% }\end{array}$ & 8 & 13250.24 & 1.86 & 106001.92 & 7123.78 & 1.84 & 26.31 \\
\hline $\begin{array}{c}\text { Gel } \\
\text { filtration }\end{array}$ & 22 & 4154.89 & 0.049 & 91407.58 & 84793.67 & 22.002 & 22.69 \\
\hline
\end{tabular}

Fig.1 Standard Graph for Maltose

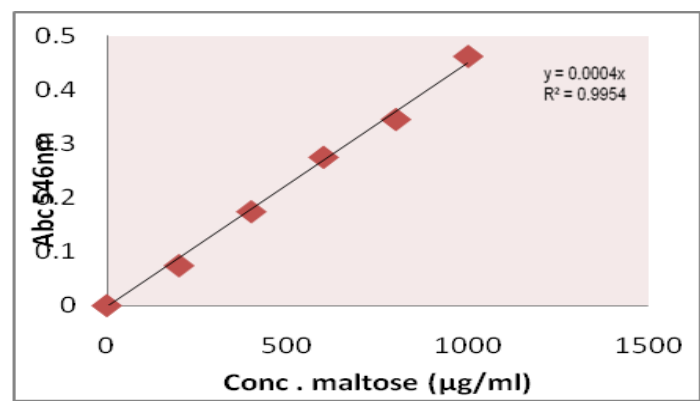

Fig.2 Standard Graph for Bovine Serum Albumin

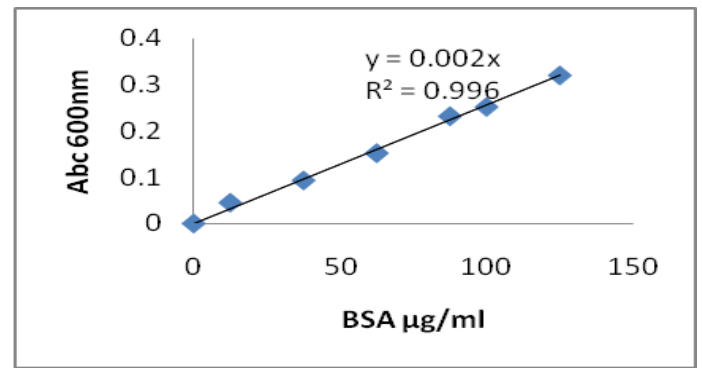


Fig.3 Gel Filtration Chromatography for A-Amylase in Oat Seeds Treated by Microwave on Sephadex G-75(1.6*65cm) Column Eluted with Potassium Phosphate Buffer (0.1m: Ph 7.0) with A Flow Rate of (18 M1/Hr) (Protein Activity)

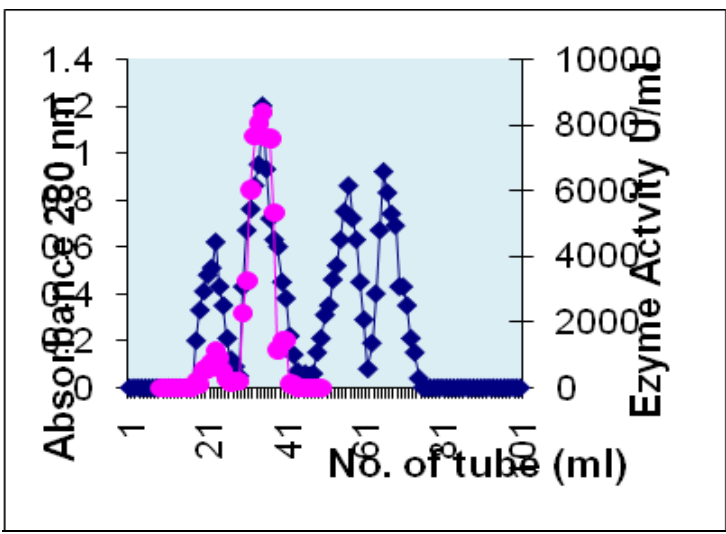

Fig.4 Gel Filtration Chromatography for A-Amylase from Untreated Oat Seeds on Sephadex G-75(1.6*65 cm) Column Eluted with Potassium Phosphate Buffer $(0.1 \mathrm{~m}: \mathrm{Ph} 7.0)$ with A Flow Rate of (18 Ml/Hr) (Protein, Activity)

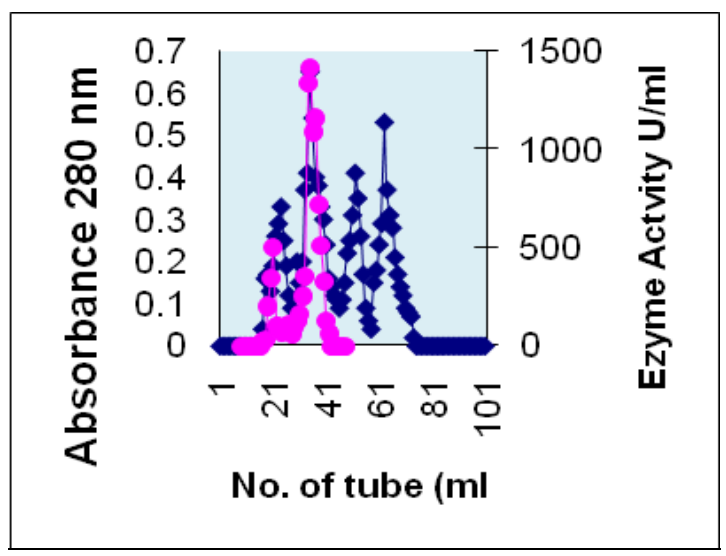

Fig.5 Effect of Temperature on A-Amylase Activity Treated Oat Seed

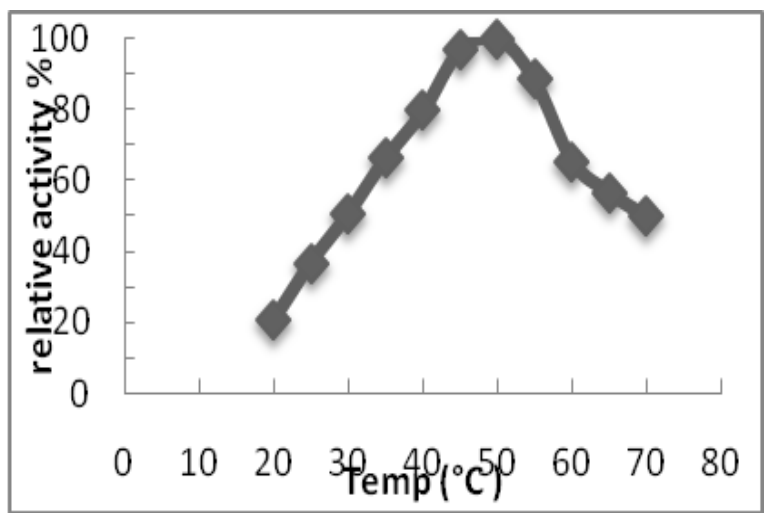


Fig.6 Effect of Temperature on A-Amylase Activity from Untreated Oat Seed

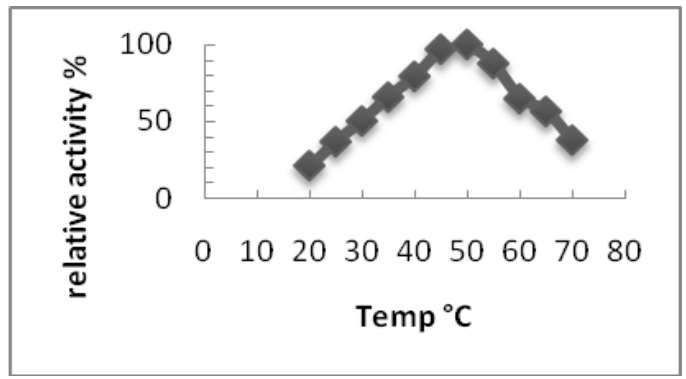

Fig.7 Effect of Ph on A-Amylase Activity in Untreated Oat Seeds

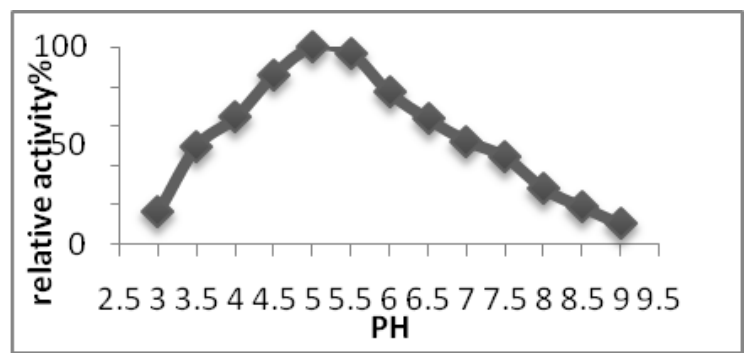

Fig.8 Effect of Ph on A-Amylase Activity in Oat 30sec Microwave Irradiated Seeds

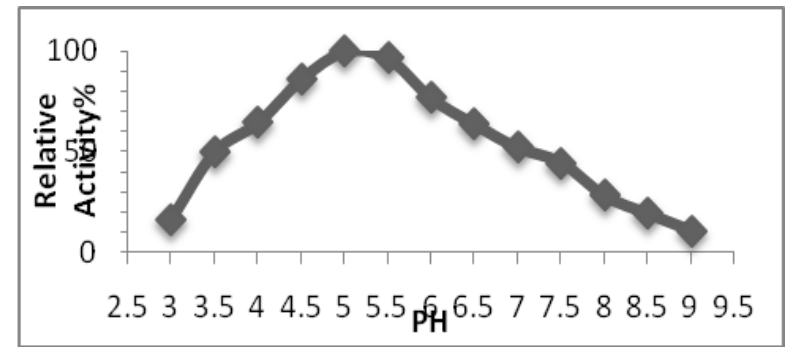

Fig.9 Linewear - Burk Plot for Untreated Oat Seeds

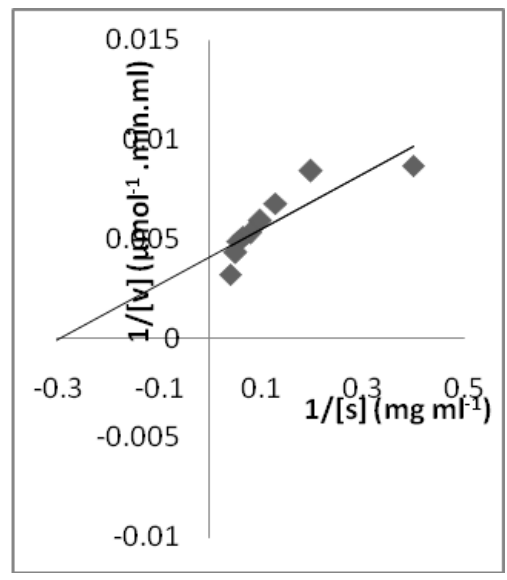


Fig.10 Linewear - Burk Plot for Treated Oat Seeds

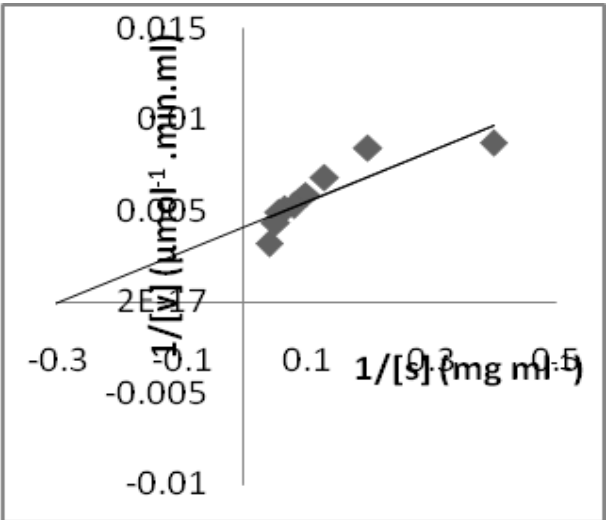

Fig.11 Standard Curve for Proteins Molecular Weight Determination

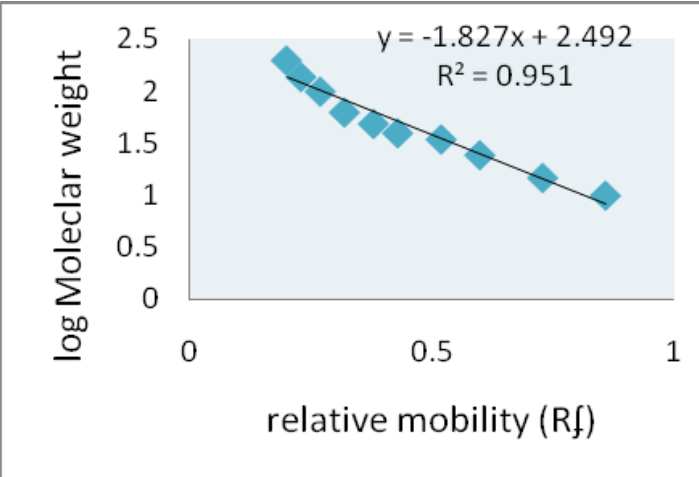

Fig.12 Photograph of Sds-Page of Alpha Amylase And Mobility of Standard Molecular Mass Marker Proteins Obtained From Sigma (A1 Crud Enzyme Untreated, A1 Crud Enzyme Treated, B1 Ammonium Sulfate Fraction 50\% for Untreated Oat, B2 Ammonium Sulfate Fraction 50\% For Treated Oat, C1 Pure Enzyme Untreated Oat, C2 Pure Enzyme Treated And S1,2 Molecular Weight Marker)

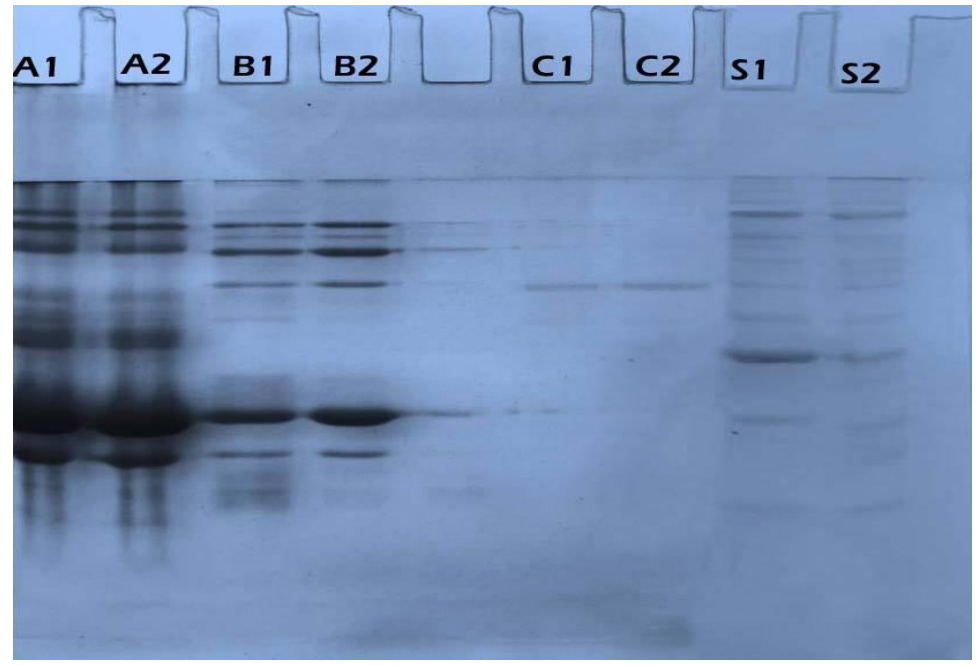


The optimum PH for enzyme activity in present study was different from that of $P$. erosus tuber $\alpha$-amylase, which expressed a maximum activity at $\mathrm{PH}$ of 7.3(Noman et al., 2006), furthermore Valaparla, (2010) reported the broad activity range (6.8-8.3) for $\alpha$-amylases from Acremonium Sporosulcatum.

The variation between these results could be due to the differences in buffers, $\mathrm{PH}$ of the solvent which cause ionization of the functional group which is present in the amino acid sequence of the active site, as well as it may causes changes in the ionic state of substrate [S], the complex between enzyme and substrate [ES] and for the enzyme product compound complex [EP], (Crabb and Shetty, 1999).

Also another effect of the PH it may cause a change in their space geometrical structure due to changes in the bonding which founded in the secondary and tertiary structure of protein part of the enzyme (Nielsen et al., 2001).

\section{$\alpha$-amylase Kinetics}

Molecular weight was determined from standard curve of known molecular weight proteins, as shown in fig (22).

The molecular weight of the purified $\alpha$ amylase was found to be $44.8311 \mathrm{KDa}$.

The two graph gave two kinetic parameters, $\mathrm{K}_{\mathrm{m}}$ and $\mathrm{V}_{\max }$. The $\mathrm{K}_{\mathrm{m}}$ values of untreated and treated malted oats were 3.25 and $3.75 \mathrm{mg}$ respectively, while the $\mathrm{V}_{\max }$ was $250 \mu \mathrm{mol} / \mathrm{min} / \mathrm{mg}$ for both, these values were similar to $\mathrm{Km}$ values reported for $\alpha$ amylases from ragi Eleusine coracana (5.9$14.3 \mathrm{mg} / \mathrm{ml}$ starch) (Nirmala and Muralikrishna, 2003a,b). And tuber Pachyhizus erosus (2.9 $\mathrm{mg} / \mathrm{ml}$ starch) (Noman et al., 2006).

\section{Molecular Weight of $\alpha$-amylase}

The molecular weight was determined by SDS-electrophoresis technique.

The molecular weight of $\alpha$-amylase found in the present study was within the range of several cereal $\alpha$-amylases such as that obtained for molecular weight of malt cereal enzymes ranged from $42-46 \mathrm{kDa}$ (Greenwood and Milne, 1968).

However, different molecular weight of 52 $\mathrm{kDa}$ was reported for amylases from malted barley (MacGregor, 1978) and 52-54 kDa for immature wheat (Marchylo et al., 1976).

The results of the present study are in agreement with results obtained by Nirmala and Muralikrisshna, (2003a,b); Majeed et al., (2011) and Usha et al., (2011) who were described that the molecular weight of $\alpha$ amylases enzyme from ragi Eleusine coracana: Malted barley and little millets, were 45, 40 and $46 \mathrm{kDa}$ respectively.

\section{References}

Adelaide, B., Varriano, M.E. 1981. Pearlmillet amylases. I. Properties of partiallypurified $\alpha$-amylase. Cereal chem, 58: 433-437.

Aladjadjian, A., Svetleva, D. 1997. Influence of Magnetron Irradiation on Common Bean (Phaseolus vulgaris L.) Seeds. Bulgarian J. Agri. Sci., 3: 741-747.

Aladjadjiyan, A. 2011. Ultrasonic Stimulation of the Development of Lentils and Wheat Seedlings. Romanian J. Biophys., 21(3): 179187.

Aladjadjiyan, A. 2012. Physical Factors for Plant Growth Stimulation Improve Food Quality, In: Food ProductionApproaches, Challenges and Tasks, 
Publisher In Tech., 145-168.

Aladjadjiyan, A. 2010. Effect of Microwave Irradiation on Seeds of Lentils (Lens Culinaris, Med). Romanian $J$. Biophysics, 20(3): 213-221.

Alfekaiki, D.F. 2013. Extraction, Purification and Characterization of alpha- amylase from germinated Sorghum seeds. Basra, 39(1B): 13 26.

Ammar, M.S. 1975. Studies on thermophilic bacteria. Ph.D., Thesis, Botany Department, faculty of science, ALAzhar University, Cairo, Egypt.

Beers, E., Duke, S. 1990. Characterization of $\alpha$-amylase from shoots and cotyledons of pea (Pisum sativum L.) seedlings. Plant Physiol., 92: 1154 1163.

Bernfeld, P. 1955. Amylases alpha and beta. In: Colowick, S.P., Kaplan, N.O. (Eds.), Methods in enzymology, vol. 1. Academic Press, New York, pp: 149-158.

Bhaskara, R.M.V., Kushalappa, A.C., Raghavan, G.S.V., Stevenson, M.M.P. 1995. Eradication of seed borne Diaporthe phaseolorum in Soybean by microwave treatment. 16th Annual meeting Biochem., 38: 1599-1616.

Chen, Y.P., Jia, J.F., Han, X.L. 2009. Weak microwave can alleviate water deficit induced by osmotic stress in wheat seedlings. Planta, 229(2): 291-298.

Crabb, W.D., Shetty, J.K. 1999. Commodity scale production of sugars from starches. Current Option in Microbiol., 2: 252-256.

Fahmy, A.S., Mohamed, M.A., Mohamed, T.M., Mohamed, S.A. 2000. Distribution of $\alpha$-amylase in the Gramineae. Partial purification and characterization of $\alpha$-amylase from Egyptian cultivar of wheat Triticum aestivium. Bull NRC Egypt, 25: 61-
80.

Greenwood, C.T., Milne, E.A. 1968. Studies on starch degrading enzymes. Part VIII. A comparison of $\alpha$-amylase from different sources: Their properties and action pattern. Die Starke, 20(5): 139-150.

Iuliana, C., Caprita, R., Giancarla, V., Ropciuc Sorina, R., Genoveva, B. 2013. Influence of Microwave Treatment on Root Growth Dynamics in Some Genotypes of Barley (Hordeum Vulgare). Ani. Sci. Biotechnol., 46: 171-185.

Kumar, R.S.S., Singh, S.A., Rao, A.G.A. 2005. Thermal stability of $\alpha$-amylases from malted jowar (Sorghum bicolor). J. Agric. Food Chem., 53: 6883-6888.

Lineweaver, H., Burk, D. 1934. The determination of enzyme dissociation constants. J. Amer. Chem. Soc., 56: 658-666.

Lowry, O.H., Rosobrough, N., Far, A.L., Randall, R.J. 1951. Protein measurement with folin phenol reagent. J. Biol. Chem., 1: 265-270.

MacGregor, A.W. 1978. $\alpha$-amylase I from malted barley-Physical properties and action pattern on amylose. Cereal Chem., 55: 754-765.

Machaiah, J.P., Vakil, U.K. 1981. Purification and physicochemical properties of $\alpha$ - amylase from irradiated wheat. J. Biosci., 3(2): 105116.

Maciunska, J., Czyz, B., Synowiecki, J. 1998. Isolation and some properties of $\beta$-galactosidase from the thermophilic bacterium Thermus thermophilus. Food Chem., 63: 441-445.

Majeed, G.H., Sahi, A.A., Alfekaiki, F.D. 2011. Purification and Characterization of alpha-amylase produced from a local Malt Barley. Basra J. Sci., 5B(37): 93-103.

Marchylo, B., Kruger, J.E., Irvine, G.N. 
1976. $\alpha$-amylase from immature hard red spring wheat. I. Purification and some chemical and physical properties. Cereal Chem., 53: 157173.

Mohamed, S.A., Al-Malaki, A.L., Kumosani, T.A. 2009. Partial purification and Characterization of Five $\alpha$-amylases from a Wheat Local Variety (Balady) During Germination. Australian J. Basic and Appl. Sci., 3(3): 1740-1748.

Mullin, J. 1995. Microwave processing. In New Methods of Food Preservation, ed. G.W. Gould. Bishopbriggs, Glasgow: Blackie Academic and Professional, pp. 112-134.

Muralikrishna, G., Nirmala, M. 2005. Cereal $\alpha$-amylases-an overview. Carbohydr. Polym., 60: 163-173.

Nielsen, J.E., Borchert, T.V., Uriend, G. 2001. The determinants of $\alpha$-amylase pH - activity profiles. Protein Engineering, 14(7): 505-512.

Nirmala, M., Muralikrishna, G. 2002. Changes in starch during malting of finger millet (Ragi, Eleusinecoracana, Indaf-15) and in vitro digestibility studies using purified ragi amylases. European Food Res. Technol., 215: 327-333.

Nirmala, M., Muralikrishna, G. 2003a. Properties of three purified $\alpha$ amylases from malted finger millet (Ragi, Eleusinecoracana,Indaf15).Carbohydrate Polymers, 54: 4350.

Nirmala, M., Muralikrishna, G. 2003b. Three $\alpha$-amylases from malted finger millet (ragi,Eleusine coracana, Indaf15)-Purification and partial characterization. Phytochem., 62: 2130.

Noman, A.S.M., Hoque, M.A., Sen, P.K., Karim, M.R. 2006. Purification and some properties of $\alpha$-amylase from post-harvest Pachyrhizus erosus L. tuber. Food Chem., 99: 444-449.

Osman, A.M. 2002. The advantages of using natural substrate-based methods in assessing the roles and synergistic and competitive interactions of barley malt starch-degrading enzymes. $J$. Inst. Brew., 108(2): 204-214.

Rajagopal, V. 2009. Disinfestation of Stored Grain Insects Using Microwave Energy, PhD Thesis, University of Manitoba, USA.

Routray, W., Orsat, V. 2011. Microwaveassisted extraction of flavonoids: a review. Food Bioprocess Technol., 5: 409-424.

SAS. 2002, 2003. Statistical analysis system, user's guide for personal computer. Version 9.1 SAS Institute Inc. Cary, NC, USA.

Segel, I.H. 1976. Biochemical calculation. $2^{\text {nd }}$ edition, john Wiley and sons. New work.

Soltani, F., Kashi, A., Arghavani, M. 2006. Effect of magnetic field on Asparagus originalis L, Seed germination and seedling growth. Seed Sci. Technol., 34(2): 349-353.

Synowiecki, J. 2007. The Use of Starch Processing Enzymes in the Food Industry. In: PolainaJ., MacCabe AP. (eds.) Industrial Enzymes. Sctructure, Function and Applications. Dordrecht: Springer, pp 19-34.

Tkachuk, R., Kruger, J.E. 1974. Wheat $\alpha$ amylases II. Physical characterization. Cereal Chem., 51: 508-529.

Usha, B., Krishna, V.G., Muni, K.D., Hemalatha, K.P.J. 2011. partial characterization of $\alpha$-amylase fromgerminating little millets (panicum sumatrense). J. Phytol., 3(1): $1-8$.

Valaparla, V.K. 2010. Purification and properties of a thermostable $\alpha-$ amylase 
sporosulcatum. Int. J. Biotech. Biochem., 6: 25-34.

Van der Maarel, M.J.E.C., van der Veen, B., Uitdehaag, J.C.M., Leemhuis, H., Dijkhuizen, L. 2002. Properties and applications of starch-converting enzymes of the $\alpha$-amylase family, $J$. Biotechnol., 94(2): 137-155.

Vijayaraghavan, P., Remya, C.S., Prakash Vincent, S.G. 2011. Production of $\alpha$ Amylase by Rhizopus microsporus using Agricultural Byproducts in Solid State Fermentation. Res. J. Microbiol., 6:
366-375.

Zhang, H.F., Yang, X.H., Wang, Y. 2011. Microwave assisted extraction of secondary metabolites from plants: current status and future directions. Trends Food Sci. Technol. 22(12): 672-688.

Zhou, Q.Z.K., Chen, X.D. 2001. Effect of temperature and $\mathrm{PH}$ on the catalytic activity of the immobilized $\beta$ galactosidase from kluyveromyces lactis. Biochem. Engineering J., 9: $33-40$.

\section{How to cite this article:}

Firdaws A. Al Mashhdani, Shno Salam Muhammed. 2016. Utilization of Microwave Treatments for Germination and $\alpha$-amylase Characteristics in Some Cereals. Int.J.Curr.Microbiol.App.Sci. 5(5): 293-306. doi: http://dx.doi.org/10.20546/ijcmas.2016.505.032 